\title{
The Unknown Carl Nielsen
}

\section{- Danish Songs in English}

\section{Indledning ved direktor Erland Kolding Nielsen}

$\mathrm{T}$ il brug for Carl Nielsen Aret 2015 - $\mathrm{i}$ anledning af 150-året for komponistens fødsel, som fejres både i Danmark og i udlandet ved en lang række begivenheder som koncerter, symposier, pressefremstød og udgivelser har Det Kongelige Bibliotek i samarbejde med pladeselskabet Dacapo produceret og udgivet cd'en The Unknown Carl Nielsen. Danish Songs in English i et usædvanligt stort oplag til brug for promoveringen og markedsføringen af Carl Nielsen i udlandet ved bl.a. disse begivenheder.

Titlen hentyder til, at som sangkomponist er Carl Nielsen i sagens natur nok relativt ukendt uden for Danmarks grænser, idet hans melodier og korsatser til danske digteres sange og salmer over 400 år jo altovervejende er skrevet til danske tekster, der hidtil kun sporadisk er oversat til engelsk.

I Carl Nielsen Udgaven, Serie III, bind 7, der udkom i 2009, findes imidlertid en total oversættelse til engelsk af alle de sang- og salmetekster, $296 \mathrm{i}$ alt, som Carl Nielsen skrev sine melodier til - altså den hidtil mest omfattende sangantologi af danske sange på engelsk - oversat og gendigtet af Holger Scheibel og Stuart Henney. Af disse har professor Niels Krabbe udvalgt 26 og skrevet en indføring, "Nielsen and the Danish Singing Tradition".

Korsangene er indsunget af Ars Nova Copenhagen, dirigeret af Michael Bojesen
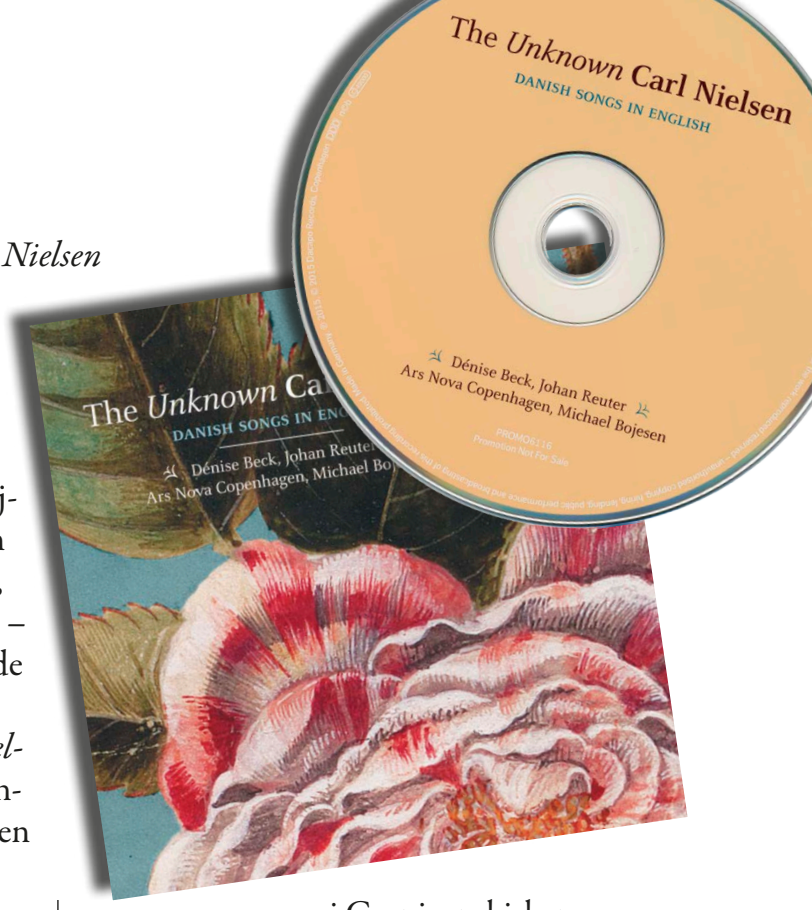

i Garnisonskirken og

solosangene af henholdsvis sopranen Dénise Beck med pianisten Clemens Hund-Göschel og barytonen Johan Reuter med pianisten Jan Phillip Schultze i Det Kongelige Biblioteks Dronningesal. Cd'en er udgivet med meget omfattende støtte fra Kulturministeriets udviklingsmidler, Carl Nielsen og Anne Marie CarlNielsens Legat og Oticonfonden.

$\mathrm{N}$ edenstående artikel er den danske version af cd'ens introduktion til Carl Nielsen som sangkomponist. Alle væsentlige begivenheder m.m. kan i øvrigt findes på Carl Nielsen Netværkets fælles nationale hjemmeside <www.carlnielsen.org >, Carl Nielsen Udgaven på < www.kb.dk/da/nb/ $\mathrm{dcm} / \mathrm{cnu}>$, og yderligere oplysninger om Carl Nielsen på < www.kb.dk> og Dansk Center for Musikudgivelses hjemmeside $<w w w . k b . d k / d a / n b / d c m>$. 


\section{Carl Nielsens Sange}

\author{
afprofessor emer. Niels Krabbe, \\ hovedredaktor af Carl Nielsen Udgaven
}

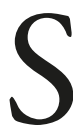
pørger man den almindelige dansker "på gaden" om, hvor mange symfonier Carl Nielsen har skrevet, eller - endnu værre - hvor mange strygekvartetter eller koncerter, vil sikkert mange blive svar skyldig. Beder man derimod de samme mennesker nævne titlen på 15-20 af hans sange, vil langt de fleste kunne opregne en liste med titler samt nynne de pågældende melodier. En stor del af Nielsens mange sange har nemlig gennem de sidste knap 100 år været en fast bestanddel af den danske kultur og er blevet sunget i talrige sammenhænge i hjemmene, i skolen, i kirken, på folkehøjskolerne og i de mange foreninger og folkelige organisationer, som Danmark er så rig på. De har - på godt og ondt, vil nogen sige - bidraget til danskernes forståelse af, hvad det vil sige at være dansk, samtidig med at de har udbredt kendskabet til noget af den fineste danske poesi, der er skrevet i det 19. og tidlige 20. århundrede. Man taler undertiden om "den danske sangskat", og heri indgår Nielsens sange som et helt afgørende element.

Den særlige tradition for fællesang $\mathrm{i}$ Danmark - også i sammenhænge uden for den kirkelige menighedssang - udspringer af den almindelige nationale nederlagsstemning, som var en følge af de katastrofale begivenheder i den anden slesvigske krig i 1864 og tabet af omkring en tredjedel af det danske rige. Dette førte til en form for national besindelse og opstramning, som gav sig en række udslag ikke mindst i form af en folkelig, national opdragelse, hvori først og fremmest N.F.S. Grundtvigs tanker om betydningen af historien, litteraturen, kristendommen og det folkelige fællesskab spillede en afgørende rolle og førte til opblomstringen af de danske folkehøjskoler - dvs. skoler, hvor specielt landbefolkningen under ubundne og eksamensfrie former kunne suge til sig af dannelse og lærdom, og hvor sang og fortælling blev de afgørende pædagogiske virkemidler.

En af de mange vigtige udløbere af den danske folkehøjskoletradition

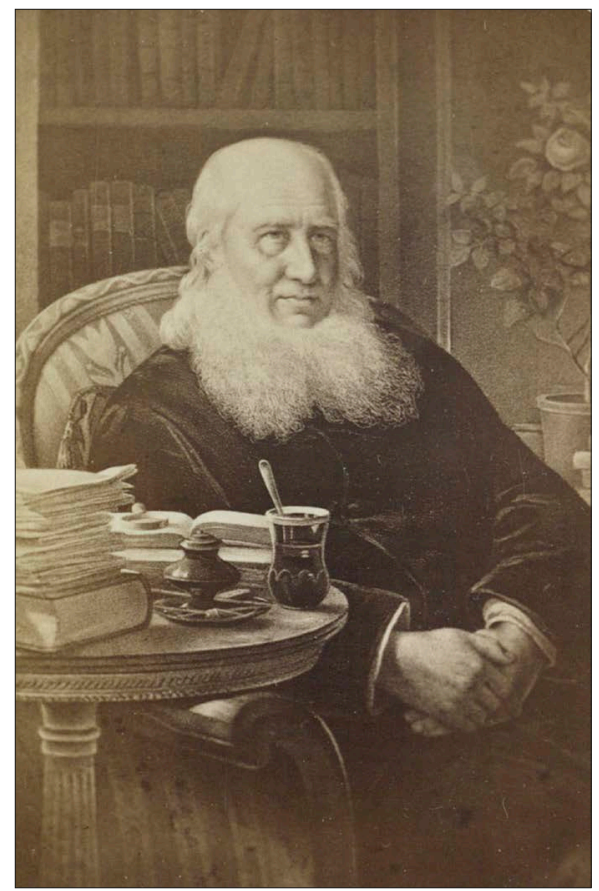

N.F.S. Grundtvig (1783-1872) prest, forfatter, historiker. Fotografi efter maleri af Wilhelm Marstrand, 1862. Det Kongelige Bibliotek, Kort- og Billedsamlingen. 
i slutningen af det 19 . århundrede var ønsket om en højnelse af kvaliteten af de melodier, der blev anvendt ved fællessangen på skolerne. I de første årtier efter 1864 bestod melodistoffet overvejende af dels romanceprægede melodier bedre egnet til solosang end til fællessang, dels af allerede eksisterende, ofte lidt tarvelige melodier, som kun passede dårligt til de tekster, som de blev sat sammen med. Det vigtigste redskab i denne renselsesproces var Højskolesangbogen med tilhørende melodibog, som gennem tiderne er udkommet $i$ talrige reviderede udgaver, og som den dag i dag er den mest anvendte sangbog i Danmark. I hele denne proces har Carl Nielsen - som primus inter pares i forhold til et par andre komponister med sine sange sat en standard og skabt en tradition, som har været bæredygtig frem til i dag.

\section{Omfang}

Carl Nielsens samlede produktion af sange omfatter ikke færre end 296 forskellige værker, hvoraf en del er overleveret i flere forskellige versioner fra komponistens hånd. Det samlede antal satser når herved op på 431 - alle gengivet i den samlede, videnskabelige udgave af Carl Nielsens værker, (CNU, Serie III, bind 4-7). Udgaven gengiver en engelsk, sangbar oversættelse af teksterne, udarbejdet af Holger Scheibel, som også er anvendt på denne cd. Af de 296 sange er i Nielsens hånd overleveret 48 sange $\mathrm{i}$ to versioner, 26 sange i tre versioner, syv sange i fire versioner, en sang i seks versioner, og en sang ("Der er et yndigt Land") i ikke færre end syv versioner. Som der er redegjort for i det følgende, omfatter denne store produktion dels et lille antal kunstsange med fuldt udskrevet klaverakkompagne- ment til koncertbrug, dels et stort antal folkelige sange enten med et selvstændigt - men enkelt - klaverakkompagnement eller som harmoniseret klaversats som ledsagelse til fællessang. Det er specielt den sidste gruppe sange, der har sat sit præg på den danske kulturarv, og hvortil de 50 mest kendte sange af Nielsen hører - sange, som er kendt og elsket af store dele af den danske befolkning samtidig med at de, af sproglige grunde, er stort set ukendte uden for landets grænser. Det sidste er baggrunden for udgivelsen af nærværende cd med et udvalg på 16 sange og 10 korsatser.

\section{Kunstsange}

Carl Nielsens sange er fordelt over hele hans aktive periode som komponist, fra de tidligste sange fra slutningen af 1880 'erne til den formentlig sidste solosang, som er dateret 4. januar 1930 til en vemodig tekst af Frederik Paludan-Müller om livets forgængelighed og om gensynet med det tabte efter døden (Gensyn, "Hvor blev den Blomst, som fyldte"). De romanceagtige kunstsange falder fortrinsvis i de tidlige år, mens gennembruddet for den folkelige sang er koncentreret om perioden ca. 1906-1926. Gennem hele perioden gælder det, at arbejdet med disse små former forløb sideløbende med kompositionen af de store orkester-, kammermusik- og korværker, og sangene var for komponisten lige så vigtige og fik lige så megen opmærksomhed som de store værker.

De første trykte sange udkom i 1890 'erne i tre samlinger som henholdsvis opus 4, 6 og 10 til tekster af to af de betydeligste repræsentanter for den tids danske lyrik, fritænkeren J.P. Jacobsen (1847-1885) og symbolisten Ludvig Holstein (1864-1943). 
Følgende sange er indeholdt på cd'en

\section{The Unknown Carl Nielsen}

(numrene i parentes henviser til Carl Nielsen Udgaven, Serie III, bind 4-6):

\section{Solosange:}

Solnedgang (1)

Irmelin Rose (4)

Ableblomst (11)

Sang bag Ploven ("I Solen gaar jeg bag min Plov") (14) Jens Vejmand (22)

"Sænk kun dit Hoved, du Blomst" (23)

Hjemvee ("Underlige Aftenlufte!") (90)

“Jeg bærer med Smil min Byrde" (97)

“Tidt er jeg glad, og vil dog gerne græde" (101)

"Min Pige er saa lys som Rav" (118)

"Som en rejselysten Flaade" (124)

“Tunge, mørke Natteskyer" (137)

"Frihed er det bedste Guld" (142)

"Nu lyser Løv i Lunde" (143)

"Solen er saa rød, Mor" (183)

"Den danske Sang er en ung, blond Pige" (191)

\section{Korsange:}

"Det bødes der for i lange Aar" (317)

Edderkoppens Sang af 'Aladdin' (384)

Morten Borups Majvise ("Frydeligt med Jubelkor") (387)

Serenade (302)

Aftenstemning ("Alt Skoven sig fordunkler”) (321)

Paaske-Liljen ("Paaskeblomst! En Draabe stærk") (324)

"Der er et yndigt Land" (308)

"Vaaren - Vaaren er i Brud" (313)

"Blomsterstøv fra Blomsterbæger" (295)

Kvadet om Nordens Harpe (332)
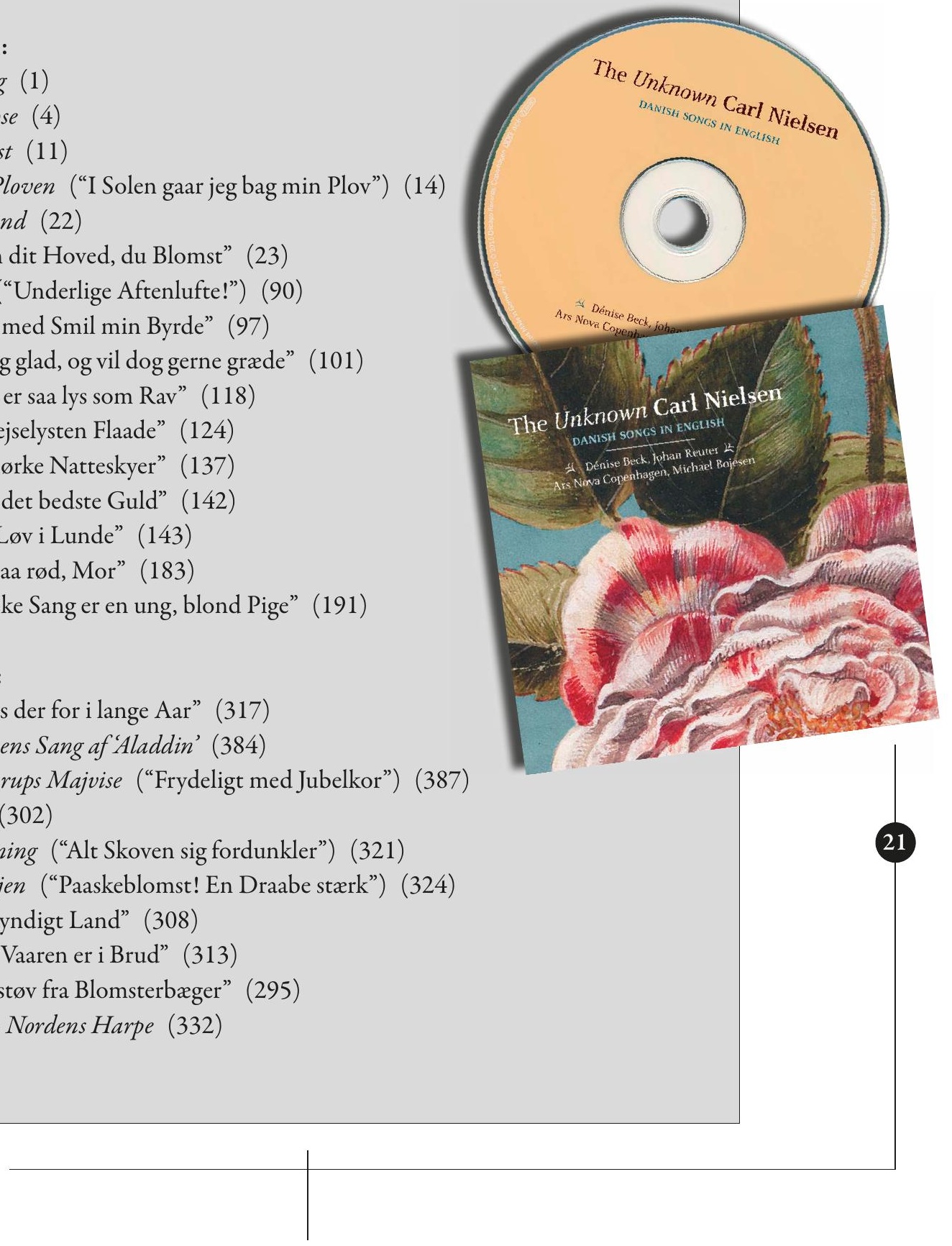
Carl Nielsen havde forinden gennem længere tid været stærkt optaget af J.P. Jacobsens digtning, hvis radikale holdning til kristendom og moral og hvis tilknytning til kredsen omkring det såkaldte "moderne gennembrud" i dansk litteratur har virket appellerende på den unge komponist. I forbindelse med arbejdet med disse samlinger ytrede Nielsen sig om forholdet mellem den gennemkomponerede og den strofiske sang på en måde, som må virke overraskende på baggrund af den store produktion af strofiske sange, som siden fulgte. I et brev af 3. maj 1888 til sin ungdomselskede forklarede han i forbindelse med betydningen af teksten i Schuberts sange: "Han [Schubert] læste sin tekst atter og atter igennem, indtil han var hel gennemtrængt af Digtets Aand og Stemning, og saa skrev han sin dejlige Musik dertil. Han opfandt den Kunst at gennemkomponere et Digt, d.v.s. sætte Musik til hele Digtet, ikke som førhen, at hvert Vers gik på samme Melodi."

De to Jacobsen-sange på denne cd (Solnedgang og Irmelin Rose) handler om to helt forskellige, fiktive kvinder: den fjerne elskede Asali og den middelalderlige stolte prinsesse Irmelin, der afviser sine bejlere én efter én. I sidstnævnte digt har Carl Nielsen ganske vist bibeholdt J.P. Jacobsens strofiske form men nærlæst digtet og tilrettet det skiftende akkompagnement digtets handling. Nielsen-ægteparrets ældste datter, som blev født i 1891, var i øvrigt opkaldt efter sangens kongedatter. Sangene fik deres første offentlige opførelse i april 1892 kort før udgivelsen, og en anmelder sammenfattede sit syn på den unge komponists arbejder således: "Der er fine træk, også poesi i denne musik for en sangstemme og klaver, men man må dog håbe at det ikke er denne vej, der skal vandres i fremtiden". Det skulle vise sig, at det var det heller ikke.

Så er der anderledes jordbund bag de to sange fra sangsamlingen fra 1895 til tekster af Ludvig Holstein (Æbleblomst og Sang bag Ploven). I førstnævntes fine lille samtale mellem digteren og de hvide æbleblomster på træet spiller akkompagnementet en stor rolle i beskrivelsen af replikskiftet, kulminerende i æbleblomsternes dryssen ned på græsset ved sommerens komme. Den anden sang skildrer måske en scene fra Nielsens barndom på Fyn med den unge landmand, som reflekterer over sin kærlighedslykke, mens han vandrer bag ploven dagen lang. Sangen er rent strofisk men med et fuldt udskrevet klaverakkompagnement, hvori man næsten kan høre plovskæret og hestenes trofaste traven hen over marken.

\section{Den "folkelige sang"}

Selvom Carl Nielsen i sin samtid havde svært ved at slå igennem som komponist i bredere kredse, blev hans mange folkelige sange dog hurtigt fælleseje, og sangene blev udgivet $i$ aviser, i små hæfter eller som en del af tidens gængse sangbøger. De fleste er skrevet på komponistens egen foranledning, men efterhånden som han blev kendt som sangkomponist, henvendte en række kendte danske digtere sig til ham med anmodninger om, at han ville sætte et af deres digte i musik. Undertiden kan man ligefrem følge en løbende dialog mellem digter og komponist om detaljer i kombinationen af tekst og musik - altså en form for indsigt i selve værkstedet. Hovedparten af sangene er skrevet $i$ årene mellem 1906 og 1926, dvs. samme periode, hvor også de tre "midterste" symfonier - nummer 3, 4 og 5 - blev komponeret. I et brev fra 1922 til hustruen Anne Marie 


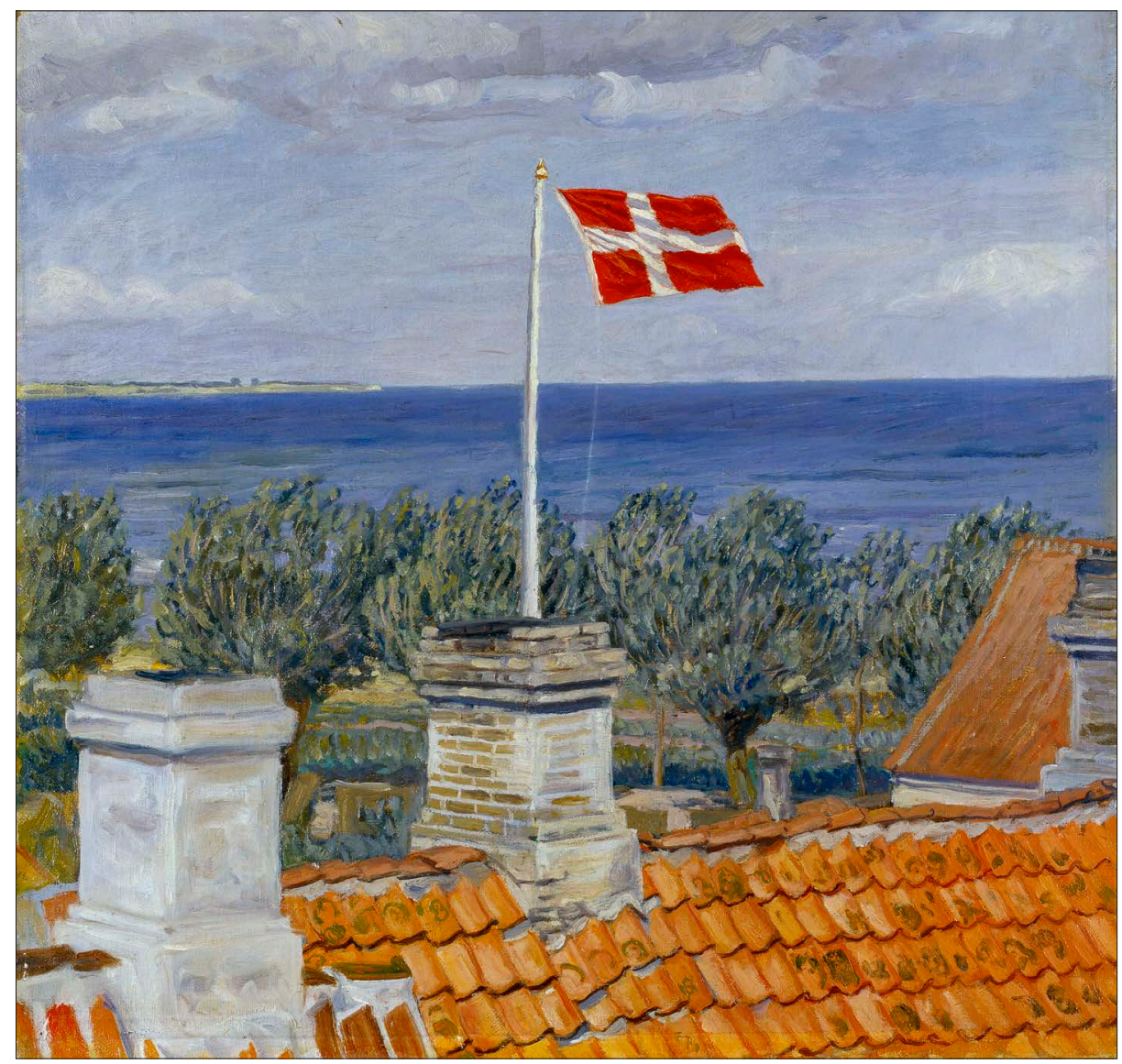

Johannes Larsen: Sommer, solskin og blest, 1899. Foto: Pernille Klemp. Ordrupgaard, København

Carl-Nielsen beskriver komponisten på sin typiske jævne måde sit arbejde med sangene: "Det er underligt, at naar jeg skriver disse letfattelige, enkle Melodier, er det som om det slet ikke er mig der komponerer; det er som om - hvad skal jeg sige - det er Folk i min Barndom ovre på Fyn eller som om det var det danske Folk som ønsker noget igennem mig. Men det lyder maaske saa stort, da Sagen er saa jævn og simpel, ihverfald for mig." Og et andet sted forklarer han, at han oplever, hvordan det er venner og folk fra landet, der ønsker sangene på den måde, og han selv - Carl - kun er “... det Rør hvorigennem Strømmen går”.

Den tidligste samling med folkelige sange udkom i 1907 og slog øjeblikkelig hans navn fast i den offentlige bevidsthed. Med den karakteristiske titel Strofiske Sange udsendte han et lille hæfte med syv sådanne sange, herunder to af sangene på denne cd (Jens Vejmand og "Sænk kun dit Hoved, du Blomst"). Ikke alle sange fra denne samling har endnu helt lagt præget af kunstsang bag sig, og faktisk er det kun 
Jens Vejmand, der fuldt og helt lever op til de idealer, som Nielsen senere satte for den folkelige sang. Til gengæld blev netop denne sang fra sin fremkomst og til i dag Nielsens mest elskede - i en sådan grad, at selv komponisten af og til synes det blev "for meget af det gode". Hertil bidrog også i høj grad den socialrealistiske tekst, skrevet af Nielsens gode ven og beundrer, almuedigteren Jeppe Aakjær (18661930), hvis tekster i det hele taget stod hans hjerte meget nær. I et avisinterview godt 10 år senere fortalte Carl Nielsen om tilblivelsen af melodien til Jens Vejmand; efter at have fortalt om arbejdet med symfonierne og kammermusikken fortsætter han: "Med de smaa Arbejder er det anderledes. Der er ingen tid til Udvikling, og dér må jeg vente, til Øjeblikket kommer. Det kan komme straks, men det kan også lade vente på sig. Og der ligger ofte for mig et stort Arbejde bag en lille Ting. F.eks. Melodien til 'Jens Vejmand' kostede mig mange - vist over 50 - forgæves Forsøg gennem 3-4 Maaneder; jeg syntes at alle de Melodier jeg havde fundet, var for kunstige, og jeg havde egentlig slået Digtet helt af Tankerne. Men så en skøn Dag meldte Melodien sig ganske af sig selv - en Dag, jeg stod og skulle med Toget til Klampenborg - og saa var den nedskrevet i Løbet af faa Minutter".

Den anden af sangene på denne cd fra Nielsens første trykte samling, "Sænk kun dit Hoved, du Blomst", er skrevet til en tekst af symbolisten Johannes Jørgensen (1866-1956), der allerede på dette tidspunkt var konverteret til katolicismen og netop i 1907 havde skrevet sin berømte biografi om Frans af Assisi, der senere gjorde ham til æresborger i Assisi. Carl Nielsen havde tidligere arbejdet sammen med Jørgensen omkring kantaten Søvnen fra 1903, hvortil denne tekst oprindeligt var skrevet. Carl Nielsen mente dengang ikke, at den egnede sig til en kantate, men fandt teksten så smuk, at han nu anvendte det impressionistiske digt om blomsten, der lukker sin krone for natten, som forlæg for sin strofiske sang med det nænsomme klaverakkompagnement, hvor man ikke mindst hæfter sig ved den frapperende harmoniske overgang mellem næstsidste og sidste linje i digtet.

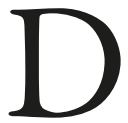
et afgørende gennembrud for nybruddet i den folkelige sang $i$ Danmark kom i årene 1915 og 1917 med de to hæfter med sange af Carl Nielsen og hans komponistkollega, kirkemusikeren Thomas Laub (1852-1927), med titlen En Snes danske Viser, indeholdende 44 tekster med halvdelen til hver af de to komponister. Fra disse to hæfter stammer følgende tre sange på denne cd: Hjemve, "Jeg bærer med Smil min Byrde" og "Tidt er jeg glad, og vil dog gerne græde". Anledningen til samarbejdet mellem Laub og Nielsen - de to stærke personligheder i tidens danske musikliv, som i mange henseender var meget forskellige - var et berømt og ofte citeret brev fra Laub til Nielsen, hvori Laub foreslog et sådant samarbejde og også skitserede en slags program for projektet. "Vil du være med?", skriver Laub, og fortsætter: "Hvad siger du om en Samling på 10-12-14 danske Viser, lavede af os to 5-6-7 af hver. Det skulle være jævne Viser, mit Forbillede er Schulz's "Lieder im Volkston" og Weyses "Morgensange". De skulle ikke henvende sig til et Musikpublikum, men til almindelige danske Mennesker. Hovedsagen skulle Ordene være, godt (strængt) valgte blandt de store danske, dem med Kraft og Natur [...] Men i og for sig er det li- 

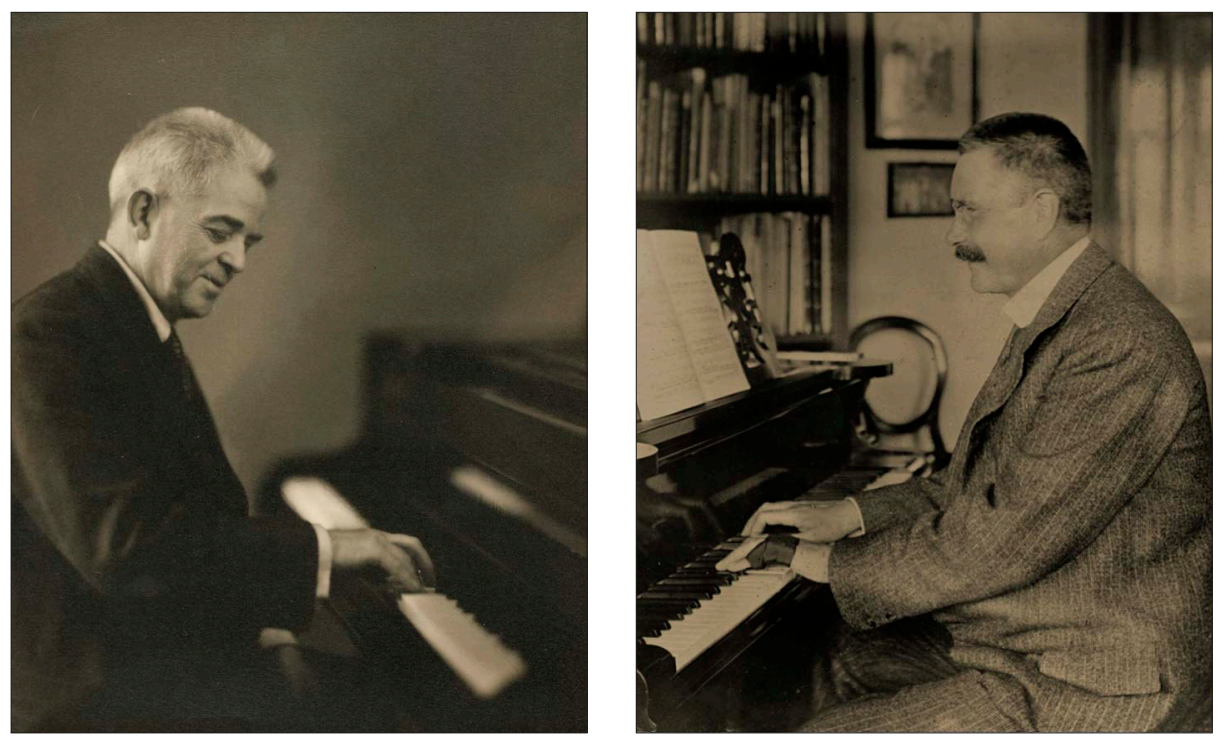

D’herrer ved klavererne: Carl Nielsen o. 1920 (foto: T.H. Andersen) og Thomas Laub o. 1910 (fotograf ukendt). Det Kongelige Bibliotek, Kort-og Billedsamlingen.

gegyldigt hvem Ordene er af, blot de har det rette danske Præg, blot vi har Lyst til at skrive Melodier til dem, og blot vi har Lyst til at lade Folk synge dem (Ordene)". Denne henvendelse med dens pædagogiske, dens nationale og dens folkelige sigte blev anledning til et af de mest frugtbare samarbejder i dansk sanghistorie. Under arbejdet var de to komponister i regelmæssig brevkontakt og kommenterede og diskuterede hinandens bidrag. Desværre er kun brevene fra Laub til Nielsen bevaret, men ikke brevene den anden vej, idet Laub øjensynligt har tilintetgjort de mange breve, han på den tid modtog fra Nielsen. I et kort forord i første hæfte citerer de to komponister den tyske komponist J.A.P. Schulz's forord fra hans Lieder im Volkston fra 1784, hvor han lancerer kravet til en god folkelig melodi med udtrykket "Schein des Bekannten" - altså det krav, som talrige af Nielsens sange netop lever op til: at sangen skal have et "skær af det velkendte" - , at selvom man ikke har hørt melodien før, skal den være formet på en sådan måde, at det lyder som om man har!

Carl Nielsen måtte igennem tre forsøg, før han var tilfreds med melodien til Adam Oehlenschlägers (1779-1850) Hjemvee ("Underlige Aftenlufte") fra 1805 - kun de to af dem er dog bevaret, skrevet to på hinanden følgende aftner. Om den første skrev Nielsen i sin dagbog 14. december 1914: "Melodi til 'Underlige Aftenlufte' (no. 1) Ikke god”. Men dagen efter hedder det: "Skrev ny Melodi - Nr. 2 - til 'Underlige Aftenlufte' af Oehlenschlæger”, og den var han øjensynlig godt tilfreds med - også selvom Laub egentlig ikke synes digtet passede til samlingen. Laub har formentlig, ligesom eftertiden, rynket på næsen af Oehlenschlägers meget svulstige digt, hvori han 


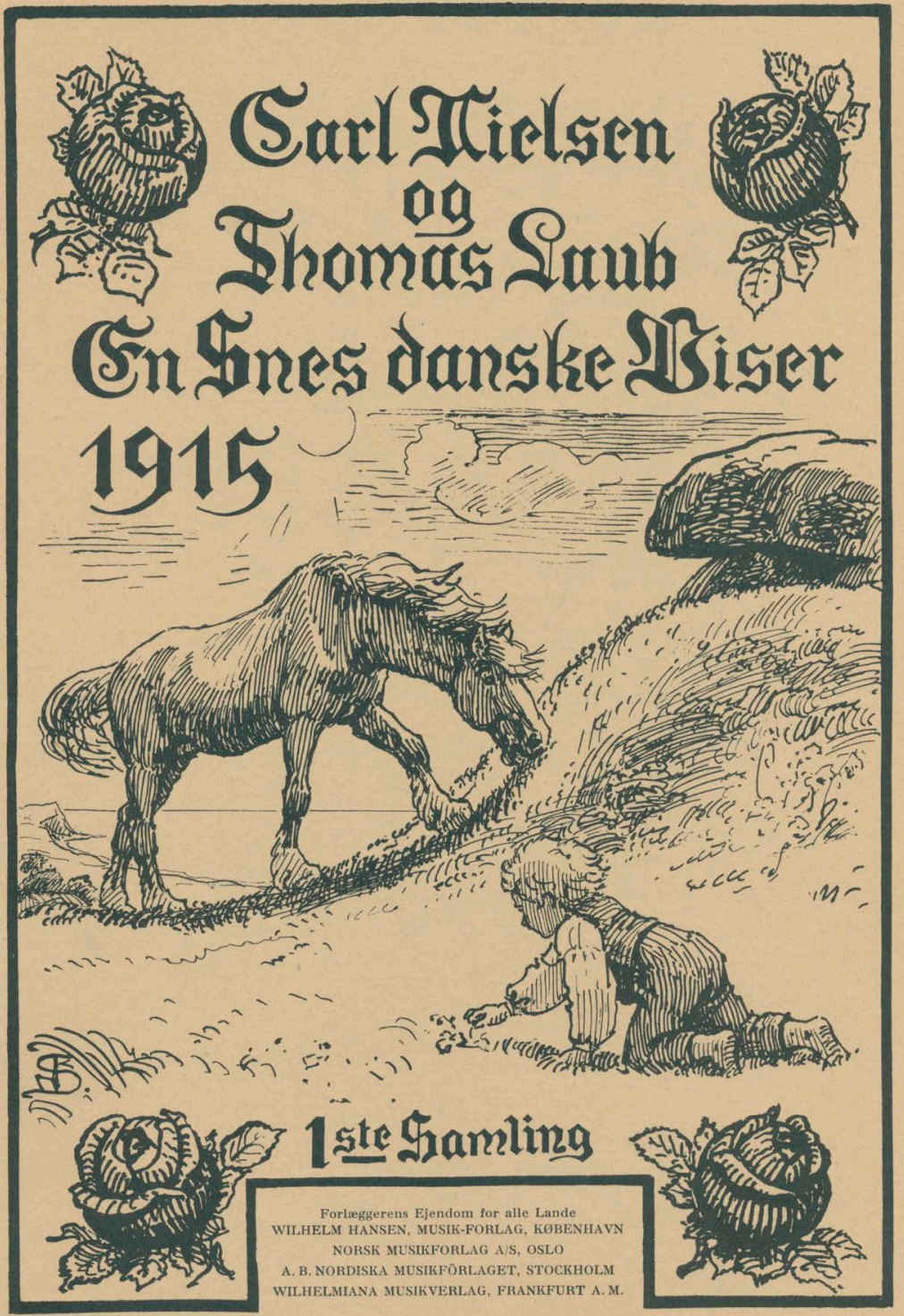

Titelbladet på forste hafte af Carl Nielsens og Laubs En Snes danske Viser, tegnet af Niels Skovgaard, er inspireret af forste vers af Poul Martin Møllers "Rosen blusser alt i Danas Have" (som med Carl Nielsens melodi indgik i haftet), specielt linjerne "Hingsten gresser stolt på Fedres Grave / Drengen plukker af de rode Ber". 
under sit lange studieophold i Tyskland beskriver sin længsel efter Danmark og den danske bøgeskov (“... min Herthas grønne Lunde” $i$ andet vers). På trods af dette og nok udelukkende i kraft af Carl Nielsens musik har sangen holdt stand og hører stadig til i nutidens danske sangkanon.

Nielsen skrev ikke færre end 18 sange til tekster af Jeppe Aakjær. Som Fynbo på landet under fattige kår følte han sig tydeligvis draget af Aakjærs hjemstavnsdigtning med rod i livet i det midtjydske og med dens beskrivelse af almuens nøjsomhed. "Jeg bærer med Smil min Byrde" fra digtsamlingen Rugens Sange fra 1906 skildrer fårehyrdens sorgløse liv i Guds frie natur, som Nielsen nænsomt understreger med sin frejdige melodi i $6 / 8$, der indledes med den for Nielsen karakteristiske faldende treklang. For at tydeliggøre sin hensigt har han oven i købet i noderne anført karakterbetegnelsen "Med bred Glæde, ligesom slentrende”.

Under sin søgen efter gode digte til at indlemme i samlingen faldt Nielsen tilfældigvis over nationalromantikeren B.S. Ingemanns (1789-1862) vemodige digt fra digtsamlingen Bekjendelser fra 1812, "Tidt er jeg glad, og vil dog gerne græde", men fandt også, at den allerede eksisterende melodi af en tidligere dansk sangkomponist, A.P. Berggreen, var ubrugelig med en klaverledsagelse, som Nielsen karakteriserede som "rent skomageragtig"! Som i så mange andre tilfælde skrev han derfor en ny - og langt bedre - melodi, som han håbede ville erstatte den allerede kendte. Dette ønske blev til fulde opfyldt, for sangen er i dag en af hans mest yndede sange både grund af sin tekst og på grund af den organiske sammensmeltning af melodi og klaverakkompagnement.
$\mathrm{M}$ ange af sangene blev oprindeligt skrevet til et af de mere end 20 skuespil, hvortil Carl Nielsen komponerede musik. Et af hans mest omfattende partiturer i denne genre er musikken til skuespillet Moderen, som Det Kongelige Teater i København bestilte til opførelse ved en festforestilling $i$ anledning af genforeningen med Sønderjylland i 1920 efter de mange år under tysk herredømme efter nederlaget i krigen i 1864. Musikken omfatter en række satser for orkester til illustration af handlingsgangen samt et antal sange, hvoraf de to mest kendte er "Som en rejselysten Flaade" og "Min Pige er saa lys som Rav". Carl Nielsen var til at begynde med noget afvisende over for opgaven, da han på dette tidspunkt havde planer om sin nye femte symfoni, men efterhånden som han kom nærmere på skuespillets tekst, blev han fanget af opgaven. Sangen "Som en rejselysten Flaade" spiller en vigtig rolle gennem hele skuespillets forløb; afsyngelsen af de seks strofer finder sted som afslutning på skuespillet som en hyldest til det genforenede Danmark; samtidig afgiver melodien temastof til et par af orkestersatserne. Den lidt mærkelige rytmiske forskydning ved overgangen til versenes anden del har altid voldt vanskeligheder, når sangen har fundet anvendelse som folkelig fællessang, hvilket den meget ofte har!

"Min Pige er saa lys som Rav" synges i skuespillet af skjalden, som mindes en pige, han engang har kendt. Den er $i$ harmonisk henseende en af Nielsens mest enkle sange, men også en af hans allersmukkeste. Eneste "udsving" er taktskiftet før omkvædet "Prinsesse Tove af Danmark". 
I 1921 udsendte Carl Nielsen en ny samling folkelige sange med titlen Tyve folkelige Melodier. I en vis forstand kan man sige, at denne samling er en slags forstudie til det, der året efter skulle blive Nielsens mest vidtrækkende og vedvarende bidrag til den danske sangtradition, nemlig redaktionen af Folkehøjskolens Melodibog. Sammen med tre komponistkolleger (hvoraf de to var Fynboer som han selv) udgav han i 1922 denne melodibog, der med sine mere end 700 satser, hvoraf ca. en femtedel var komponeret af udgiverne selv, er blevet hovedhjørnestenen i fællessangen i Danmark, som den gennem mere end 100 år har været dyrket i hjem, skole og kirke samt ikke mindst på de danske folkehøjskoler, der voksede op i kølvandet på Grundtvigs ideer om folkelig “opdragelse". Stort set samtlige 20 sange fra Tyve folkelige Melodier fandt året efter vej til Folkehøjskolens Melodibog. Tre af dem er med på nærværende cd, "Tunge, mørke Natteskyer", "Frihed er det bedste Guld” og "Nu lyser Løv i Lunde”. Også her skrev Nielsen et lille forord, hvori det bl.a. hedder, at "sådanne folkelige Melodier ikke tør komme ind under Synsvinklen: Romancer og Sange. Jeg har nemlig bestræbt mig for at holde baade Melodierne og deres harmoniske Klædning i saa jævn og letfattelig Fremtræden som vel muligt".

Teksten til "Tunge, mørke Natteskyer”, skrevet af digterpræsten Jakob Knudsen (1858-1917) i 1890, bærer fra forfatterens hånd titlen Aftenvers. Knudsen er ikke mindst kendt for sin store og dystre roman om Martin Luther, Angst og Mod, og også i Aftenvers mærker vi den knugende tungsindighed hos digteren. Nielsens melodi i mol med dens monotone bevægelse i klaverets højre hånd og den helt åbne slutning på en anden tone end grundtonen giver sangen sit helt særlige udtryk. På sin vis kalder denne sang om mørket på sin fortsættelse, som Jakob Knudsen da også skrev en måned senere med den jublende førstelinje "Se nu stiger Solen af Havets Skød," - dog ikke med melodi af Carl Nielsen, men af hans ligesindede, når det gjaldt den folkelige sang, komponisten Oluf Ring (1884-1946).

"Frihed er det bedste Guld" er med sine otte vers egentlig et bearbejdet uddrag af et langt svensk digt på mere end 30 vers, formentlig skrevet i 1439 af den svenske biskop Thomas av Strängnäs. Det er paradoksalt, at det svenske digt oprindeligt er rettet mod Danmark i forlængelse af en krig mellem Danmark og Sverige, sammenholdt med, at den korte bearbejdelse siden sin fremkomst i sidste del af 1800-tallet er blevet anvendt i forskellige protestagtige sammenhænge i Danmark eller som en almen hyldest til frihedsbegrebet. Carl Nielsens magtfulde melodi indledes - ligesom det var tilfældet med "Jeg bærer med Smil min Byrde" - med den karakteristiske treklang fra toptonen og ned på grundtonen, og er yderligere karakteriseret ved, at toneomfanget i hele sangen - altså afstanden fra den dybeste til den højeste tone - er større end i formentlig nogen anden sang af Nielsen. Hele tonen i melodien er yderligere understreget ved Nielsens karakterbetegnelse "Stærkt og frejdigt". Her er ikke noget tilbage af gammelt fjendskab mellem Danmark og Sverige, men alene en bekendelse til friheden - næsten for enhver pris.

Johannes Jørgensens digt fra 1892, "Nu lyser Løv i Lunde", er en uhildet hyldest til den nordiske sommer med dens grønne løv og lyse nætter. Med sin jævnt 
vuggende, enkle melodi er den blevet en af de mest sungne danske sange ved sommerens forskellige fester, herunder de mange fejringer af afsluttet skolegang og ikke mindst de årlige fejringer af 5. juni, dagen for underskrivelsen af den danske grundlov i 1849. Melodien, med karakterbetegnelsen "Mildt", opfylder til fulde det tidligere nævnte ideal om "skær af det velkendte".

De to sidste solo-sange på denne cd stammer fra Carl Nielsens samling fra 1926, Ti danske Smaasange. Selvom der er tale om små, korte sange, er akkompagnementerne udarbejdet med den højest tænkelige omhu som et blødt tæppe omkring selve melodien. Det høres tydeligt i børnesangen "Solen er saa rød, Mor" med barnets vedvarende appel til moderen om at forsikre, at der ikke er noget farligt ved natten, og at han trygt kan lægge sig til ro. Særlig fint virker de sidste fire takter med antydningen af en lille trestemmig kanonbegyndelse, der runder kompositionen af.

I 1925 sendte digteren Kai Hoffmann (1874-1944) sit digt "Den danske Sang er en ung, blond Pige" til Carl Nielsen med en anmodning om, at han ville forsyne det med en melodi. Hoffmann havde skrevet digtet som prolog, oplæst ved et stort anlagt nationalt landssangstævne et år tidligere men mente nu, at digtet fortjente også at kunne synges. Resultatet blev, at Carl Nielsen endnu engang skabte en sang, som vandt genlyd i brede kredse, og som næsten er kommet til at stå som en slags motto for den danske fællessang. Den første linje af sidste vers,

"Så syng da, Danmark, lad hjertet tale"

er i den seneste udgave af Højskolesangbogen fra 2006 trykt med guldtryk på

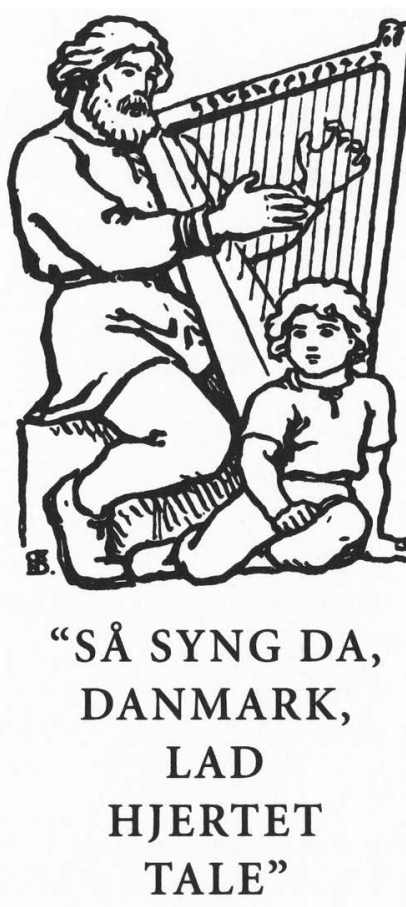

ryggen af indbindingen under vignetten af skjalden med sin harpe og den lyttende dreng ved foden.

\section{Korsange}

Fra Carl Nielsens hånd foreligger knap 100 satser for kor a cappella, både blandet kor og kor for lige stemmer, herunder såvel korbearbejdelser af tidligere skrevne sange som originale værker for kor, sidstnævnte ofte på bestilling fra skoler eller korforeninger. Samtlige satser på denne cd er originalkompositioner for kor, hvoraf den tidligste stammer fra Nielsens studietid i 1887 ("Det bødes der for i lange Aar"), mens den sidste, Kvadet om Nordens Harpe, blev komponeret i begyndelsen af april 1931, seks måneder før komponistens $\mathrm{d} ø \mathrm{~d}$. 
"Det bødes der for i lange Aar" er en af fire satser for mandskor, som Nielsen formentlig skrev på foranledning af sin højt elskede teorilærer på musikkonservatoriet i København og senere åndelige mentor, Orla Rosenhoff (1844-1905). Den tunge tekst om lykkens forgængelighed er af J.P. Jacobsen, der - som det er nævnt ovenfor - var en af de forfattere, som Carl Nielsen var allermest optaget af i sin studietid.

Manuskriptet til Edderkoppens Sang af 'Aladdin' fra 1899 for tre lige stemmer til Adam Oehlenschlägers tekst er dediceret til Carl Nielsens ungdomsveninde, Margrete Rosenberg, til hvem han bevarede et varmt forhold hele livet igennem.

De to satser, Morten Borups Majuise ("Frydeligt med Jubelkor") og "Vaaren Vaaren er i Brud" er skrevet til den samme latinske tekst i forskellig oversættelse med 20 års mellemrum i henholdsvis 1906 og 1926. Den gamle latinske tekst "In vernalis temporis" af rektor ved Aarhus' gamle latinskole, Morten Børup (14461526), går tilbage til o. 1500 og blev med tilhørende melodi trykt anonymt i en samling kirke- og skolesange med titlen Pie cantiones i 1582. Med denne melodi har digtet vundet indpas i den danske kirke, og den gamle melodi lyder stadig fra klokketårnet på rådhuset i Århus. Carl Nielsens to nye melodier blev begge til på opfordring fra danske skoler i forbindelse med deres årlige fejring af forårets komme samtidig med skoleårets afslutning: den tidlige version blev bestilt af almenskolen i Kolding, mens den sene version blev bestilt af Aarhus katedralskole i 1926 som en markering af 400-året for Morten Børups død.

Den kunstfærdige fire-stemmige sats, Serenade ("Gerne vi lytter, naar Strængene bringer") blev skrevet i forlængelse af en fødselsdagssammenkomst hos Vilhelmine Heise (1838-1912) i februar 1907. Som det fremgår af Nielsens dagbøger og de to første linjer af tredje strofe

"Takket da være den Frue, som stævner til sig de Unges frejdige Kor"

dannede fru Heises hjem rammen om en række musikalske sammenkomster, og Nielsen var en hyppig gæst. Vilhelmine Heise var enke efter den danske komponist Peter Heise (1830-1879), kendt for sine romancer og ikke mindst for sit hovedværk, operaen Drot og Marsk fra 1878. Muligvis er begyndelsen og slutningen af Nielsens sats en form for "hilsen" til Heises romantiske sangstil, mens midterdelen har et mere ægte Nielsen-præg.

$$
\text { Aftenstemning ("Alt Skoven sig }
$$

fordunkler") blev skrevet i 1908 til det københavnske herrekor Bel Canto til en oversat tekst af det tyske digt af Matthias Claudius, "Der Mond ist aufgegangen", som allerede var kendt og brugt $i$ vide kredse i Danmark til J.A.P. Schulz' melodi fra hans Lieder im Volkston fra 1782 - netop den samling, fra hvilken Nielsen og Laub syv år senere hentede deres ideal om, at den folkelige sang skulle have et "skær af det velkendte", som er nærmere omtalt i det foregående. Der er således en vis modsætning mellem dette ideal og Nielsens mere sofistikerede korsats.

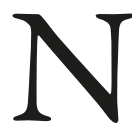
ielsens mange salmemelodier fik aldrig den samme popularitet som hans sange. Selvom han skrev op mod 50 salmemelodier, er det mindre end et halvt dusin, der har vundet indpas i den danske kirkelige tradition. Han havde ikke - på samme måde som Thomas Laub - sit naturlige hjemsted 
1. Hradutom Nondus term.

Stolt of fast ithles for lanerount.

Lanl Nilum

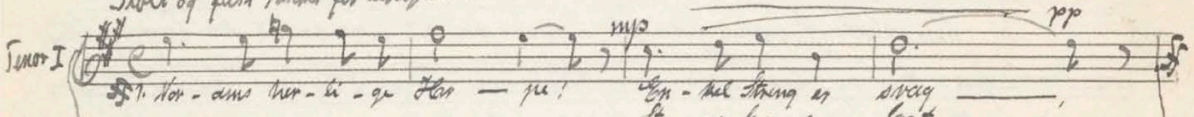

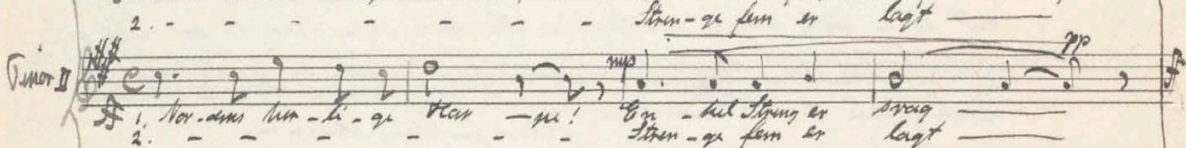

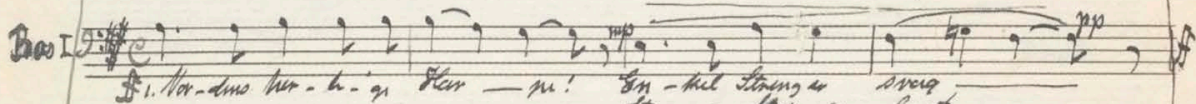

than-qu tem-ar lact

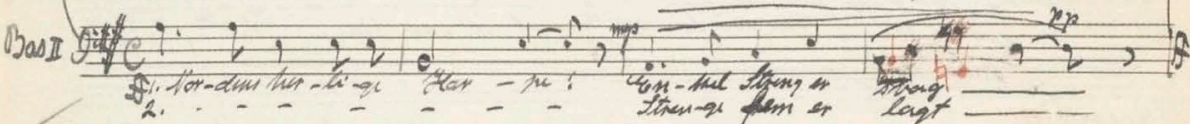

14)

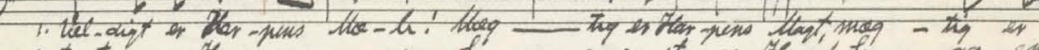

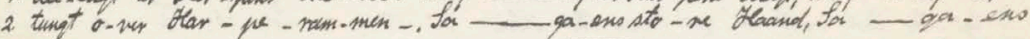

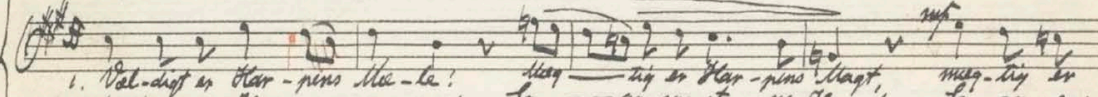

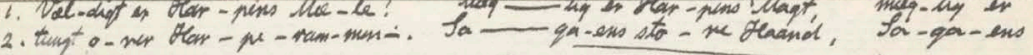

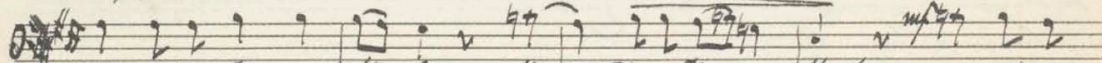

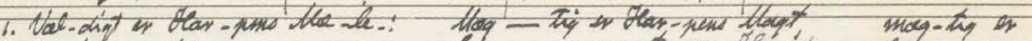

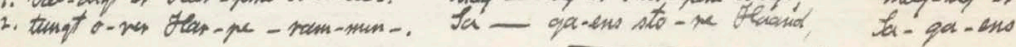

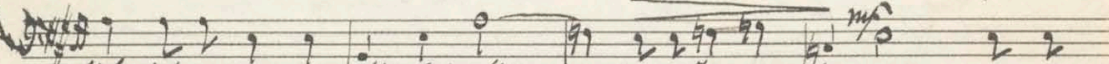

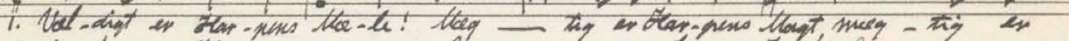

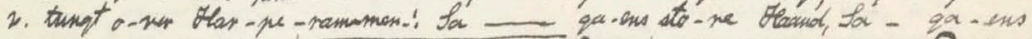

है:

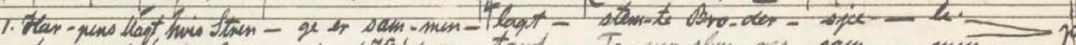

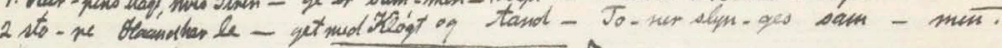

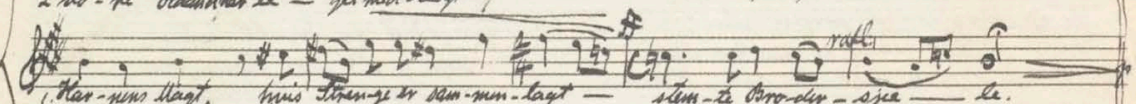

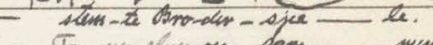

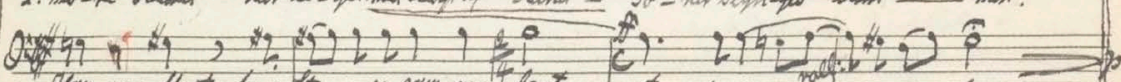

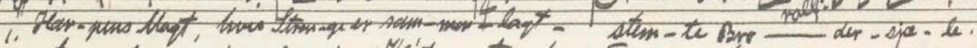

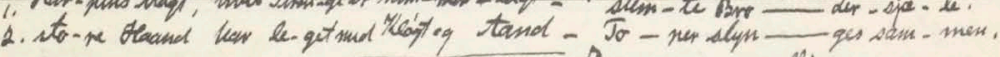

a.ti gall:

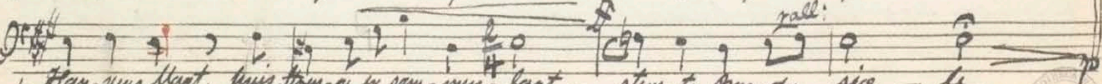

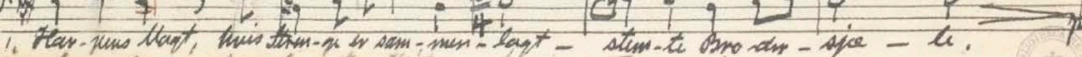

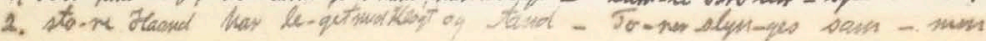

Carl Nielsens renskrift afkorsatsen Kvadet om Nordens Harpe, komponeret $i$ april 1931, seks måneder for hans dod $i$ begyndelsen af oktober samme air. 
i kirken og var næppe et troende menneske i traditionel kristelig forstand. Det at skrive salmer var derfor at betræde en form for "fremmed grund" for Nielsen. Dette ændrer dog ikke ved, at enkelte af hans salmer hører til blandt de allermest elskede og benyttede melodier i den danske kirke, hvilket ikke mindst gælder hans melodi til Grundtvigs magtfulde påskesalme, Påske-Liljen ("Paaskeblomst! En Draabe stærk"). I samme åndedrag kunne nævnes den velkendte salmemelodi, der udgør temaet for variationerne i sidste sats af Carl Nielsens blæserkvintet, der ligeledes har fastholdt sin position i kirken ("Min Jesus, lad mit Hjerte faa"). Grundtvigs digt Påske-Liljen stammer fra 1817 og bestod oprindeligt af ikke færre end 21 vers, som gennem tiden efterhånden er blevet reduceret til de nu kendte seks vers, hvormed den indgår i Den Danske Salmebog. Carl Nielsen skrev sin melodi for mandskor i 1910 og omarbejdede den for sang og klaver til den version, der siden er blevet anvendt som fællessang. I årene 1931-1942 blev sangen brugt ved den årlige festforestilling på Det Kongelige Teater, Paaske-Aften, til fordel for opførelsen af Grundtvigskirken i København, der som et monument over den danske salmedigter blev indviet i 1940 .

I 1819 udskrev Selskabet til de skjønne Videnskabers Forfremmelse en konkurrence om udarbejdelse af den bedste danske nationalsang. Konkurrencen blev vundet af den ukendte Juliane Marie Jessen, men det blev Adam Oehlenschlägers bidrag, "Der er et yndigt Land", der efterfølgende med Hans Ernst Krøyers melodi fra 1835 blev ophøjet til den danske nationalsang, og som sådan har den siden været anvendt - dels ved store nationale begivenheder, dels, og navnlig, ved sportsbegivenheder, hvor Danmark har deltaget. Gennem tiden har både Oehlenschlägers tekst og Krøyers melodi været stærkt kritiseret, og både Thomas Laub og Carl Nielsen skrev en ny melodi til sangen, uden dog at nogen af dem har formået at fortrænge Krøyers oprindelige melodi. Carl Nielsen skrev sin melodi på opfordring i slutningen af 1923, og i løbet af 1924 forelå den i ikke færre end syv forskellige udsættelser. Sangen blev under stor bevågenhed opført ved et stort korstævne i København i 1924, angiveligt af ikke færre end "900 Sangere (Damer og Herrer) fra blandede Kor i Danmarks Byer", som det hedder i programmet fra koncerten. Pressen var stærkt optaget af, at Nielsen således forsøgte at overtrumfe den velkendte melodi, og $i$ en avis hed det, at ganske vist fik sangen stort bifald ved opførelsen, "men dermed er dens Saga sikkert også ude. Thi man kasserer nu engang ikke en Sang, som er blevet hele Nationens, selv om der kom ti nye, der var bedre". Og Nielsen udtalte selv, noget sarkastisk, at han med sin nye melodi havde fået vakt folkets kærlighed til den gamle: "Så om ikke ved noget andet jeg har skrevet, saa véd jeg da, at ved min Melodi til 'Der er et yndigt Land', har jeg faaet Folket i Tale!" Ingen ville i dag kunne forestille sig, at en fodboldkamp blev indledt med nationalsangen på Carl Nielsens melodi - det vil formentlig også fremover være Krøyers som istemmes, både med forkert rytme og med falske toner!

Som flere andre af Nielsens korsatser skyldtes også udsættelsen for femstemmigt kor af Viggo Stuckenbergs (1863-1905) digt , "Blomsterstøv fra Blomsterbæger" en henvendelse fra en skole, som ønskede en sang, der kunne 
anvendes ved den årlige translokation. Sangen med betegnelsen Skolesang blev komponeret til Birkerød Statsskole nord for København i 1929.

Nielsens sidste korværk, Kvadet om Nordens Harpe ("Nordens herlige Harpe!”), kendes kun fra komponistens manuskript, der er dateret 1. april 1931. Det blev skrevet til et nordisk mandskorstævne i København i anledning af herrekoret Bel Cantos 25 års jubilæum en måned senere. Værket blev opført af alle de deltagende kor og dannede afslutningen på stævnets åbningskoncert, der blev radiotransmitteret til de øvrige nordiske lande, og komponisten var genstand for betydelig hyldest såvel fra de mange korsangere som fra avisernes anmeldere. Teksten er en hyldest til det nordiske samarbejde, hvis "enkelte Harpestreng er svag", men hvis "herlige Harpe" er stærk, når strengene er "sammenlagt". Digtet, med karakterbetegnelsen "Stolt og fast, ikke for langsom" er forfattet af Carl Niel- sens ven, Aage Berntsen (1885-1952), som tidligere havde forfattet teksten til hans kantate Fynsk Foraar.

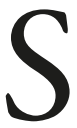
om det er fremgået af det foregående, er Carl Nielsen den danske komponist, hvis sange har haft størst betydning for den danske sang gennem de seneste mere end 100 år. Selvom nye sange er kommet til siden hans død, har de bedste af hans sange formået at holde sig levende i den brede befolknings bevidsthed. Måske ikke alle ved, at denne eller hin sang er af Carl Nielsen - men alle kan nynne melodien og få mindelser om de mange gange, hvor de har sunget den.

Carl Nielsen efterlod en række digte, fortrinsvis skrevet i 1907, som han på et tidspunkt overvejede at udgive. Et af digtene (omtalt i hans dagbog 20. maj 1907) handler om hans egne sange, "Saa flyv da ud mine Sange!" Her hedder det i strofe 3-5, hvor komponisten så at sige henvender sig direkte til sine sange:

Men herligt det var da I fødtes!

I skælvende Længsel paa Læbens Rand, i levende Dirren som Sol gjennem Vand, i Stunder hvor Tiden er ødtes;

da brast I frem, mine Sange.

$\mathrm{Nu}$ fatter jeg ikke, hvordan det gik til jeg aner kun sælsomme Kræfters spil

i Sjælens forførende Gange.

Jeg ved ej om I er smukke.

Jeg er kun en Sluse som luktes op, et Leje for Strømmen fra Bjergets Top, og kan ikke aabne og lukke.

Samtlige Carl Nielsens sange er udgivet i den samlede praktisk-videnskabelige udgave af Nielsens værker, The Carl Nielsen Edition, Series III, Vols. 4-7, København 2009.

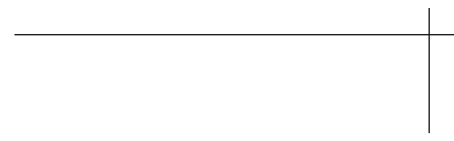

